\title{
Morphological and Optical Properties of Pure and Mg Doped Tin Oxide Thin Films Prepared by Spray Pyrolysis Method
}

\author{
Abdul Rahman Abdul Aziz Sakhta ${ }^{*}$, Ahmad Hamed Khdro, Ali Naji Darwisho \\ Department of Physics, Faculty of Science, Tishreen University, Latakia, Syria \\ Email address: \\ abdul-rahman.sakhta@hotmail.com (A. R. A. A. Sakhta) \\ ${ }^{*}$ Corresponding author
}

\section{To cite this article:}

Abdul Rahman Abdul Aziz Sakhta, Ahmad Hamed Khdro, Ali Naji Darwisho. Morphological and Optical Properties of Pure and Mg Doped Tin Oxide Thin Films Prepared by Spray Pyrolysis Method. American Journal of Nanosciences. Vol. 3, No. 2, 2017, pp. 19-23.

doi: $10.11648 /$ j.ajn.20170302.11

Received: February 8, 2017; Accepted: March 1, 2017; Published: May 8, 2017

\begin{abstract}
Pure Tin Oxide $\left(\mathrm{SnO}_{2}\right)$ and Magnesium $(\mathrm{Mg})$ doped $\mathrm{SnO}_{2}$ thin films have been deposited onto glass substrates by spray pyrolysis technique at the substrate temperature of $450^{\circ} \mathrm{C}$. The doping concentration of $\mathrm{Mg}$ was varied from 1 to $9 \mathrm{wt} \%$ (with $2 \mathrm{wt} \%$ step) while all other deposition parameters such as substrate temperature, spray rate, carrier gas pressure and distance between spray nozzle to substrate were kept constant. The surface morphology and optical properties of the deposited thin films have been studied by Scanning Electron Microscopy (SEM) and UV visible spectroscopy. Average optical transmittance in the $400-900 \mathrm{~nm}$ range varies from $18.21 \%$ to $58.99 \%$ with varying $\mathrm{Mg}$ concentration in the film. Maximum band gap value of $3.90 \mathrm{eV}$ is obtained for undoped $\mathrm{SnO}_{2}$.
\end{abstract}

Keywords: Thin Films, Spray Pyrolysis, Mg Doped Tin Oxide, Optical Properties, Scanning Electron Microscope

\section{Introduction}

In recent years, there has been considerable interest in metal oxides because of their many industrial applications, especially transparent conducting oxides (TCO). Tin oxide belongs to a transparent conductive oxide (TCO) family which are the most studied [1]. Transparent conducting oxides are semiconductors produced from a combination of metal and Oxygen. The study of $\mathrm{SnO}_{2}$ transparent conducting oxide thin films are important due to its unique attractive properties like high optical transmittance, uniformity, nontoxicity, good electrical, low resistivity, chemical inertness, stability to heat treatment, mechanical hardness, piezoelectric behavior, and its low cost. So, $\mathrm{SnO}_{2}$ is used in solar cells, sensor gas, display devices and in other important applications [2-3].

Tin Oxide is an n-type semiconductor with wide band gap energy $\left(E_{g}=3.5-4 \mathrm{eV}\right)$ [4]. Tin Oxide has a tetragonal structure. Its unit cell contains two Tin and four Oxygen atoms as is shown in Figure 1. The Tin atom is at the center of six Oxygen atoms placed at the corners of a regular octahedron. Every Oxygen atom is surrounded by three Tin atoms at the corners of an equilateral triangle $[5,6]$.

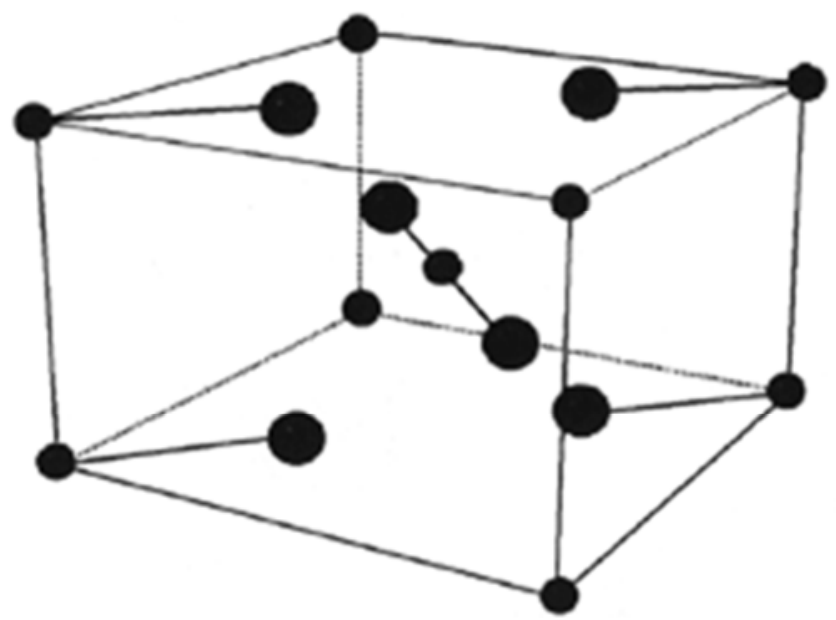

Figure 1. Unit cell of crystalline structure of $\mathrm{SnO}_{2}$. big circles represent Oxygen atoms and small circles represent Tin atoms (from [7]). 
The structure of this material in its bulk form is tetragonal with lattice parameters of $\mathrm{a}=\mathrm{b}=4.737 \mathrm{~A}^{\circ}$ and $\mathrm{c}=3.186^{\circ} \mathrm{A}$. However, in thin film form, depending on the deposition technique, its structure can be polycrystalline or amorphous. The grain size is highly dependent on the deposition technique, substrate temperature, post heat treatment and doping level [8].

So nowadays we notice the importance of thin films in our practical life and from this point many techniques in depositing thin films have appeared with high Accurate qualities such as: thermal vacuum evaporation, sputtering, pulsed laser ablation, chemical vapor deposition, chemical bath, dip coating, spin coating and spray pyrolysis [9]. The spray pyrolysis is the simplest, cheapest alternative method to manufacture thin films that is used in industrial applications [10]. There are many characteristics of this method such as: it is suitable for preparing doped and pure thin films because of their simple experimental manufacturing, we can prepare films from high melting temperature materials that we can't prepare in other methods, economic technique because the used devices don't need vacuum or complicated devices, we can add several dopants that are different in concentration, we can change deposition factors (type of used substrates - temperature of substrate composition of solution - flow rate solution - distance between the spray nozzle and substrate) to get films that have special electrical and optical properties [11].
The undoped and $\mathrm{Mg}$ doped $\mathrm{SnO}_{2}$ thin films were deposited by using a homemade spray pyrolysis apparatus in Albaath university. Starting solution of $\mathrm{SnO}_{2}$ was prepared by dissolving 1M Stannous Chloride ( $\mathrm{SnCl}_{4}, 99 \%$, Merck, Germany) in $25 \mathrm{ml}$ of Ethanol $\left(\mathrm{C}_{2} \mathrm{H}_{6} \mathrm{O}\right.$, 99.8\%, Sigma-Aldrich, Germany) and distilled water with ratio 7/3 (7 for distilled water and 3 for Ethanol) and with adding few drops of $\mathrm{HCl}$ in this solution. For $\mathrm{Mg}$ doping, Magnesium Chloride $\left(\mathrm{MgCl}_{2}, 98 \%\right.$, Riedel-de haen, Germany) was dissolved in solution as dopant material source.

In order to grow undoped and $\mathrm{Mg}$ doped $\mathrm{SnO}_{2}$ films varied from $1 \mathrm{wt} \%$ to $9 \mathrm{wt} \%$ by weight percentage (with $2 \mathrm{wt} \%$ step), the necessary amounts of these solution were prepared. All spray solutions were stirred to obtain homogenous solutions. The resultant solutions were sprayed on glass substrates (Citoglas, $7.5 \mathrm{~cm} * 2.5 \mathrm{~cm} * 0.1 \mathrm{~cm}$ ). The glass substrates were rinsed with $\mathrm{HCl}$ and then cleaned with ethanol. Finally, they were cleaned with distilled water by using an ultrasonic cleaner (Trans sonic 700/H) and then dried with air compressor.

Figure 2 shows the schematic diagram of the spray pyrolysis apparatus. The substrate temperature was fixed as $450^{\circ} \mathrm{C}$ on hot plate and controlled by temperature control unit. The nozzle to substrate distance was $25 \mathrm{~cm}$ and the time for the film deposition was about $15 \mathrm{~min}$. after the deposition operation, the substrates was kept cooled at room temperature. All experiments were done under approximately similar conditions.

\section{Experimental Procedure}

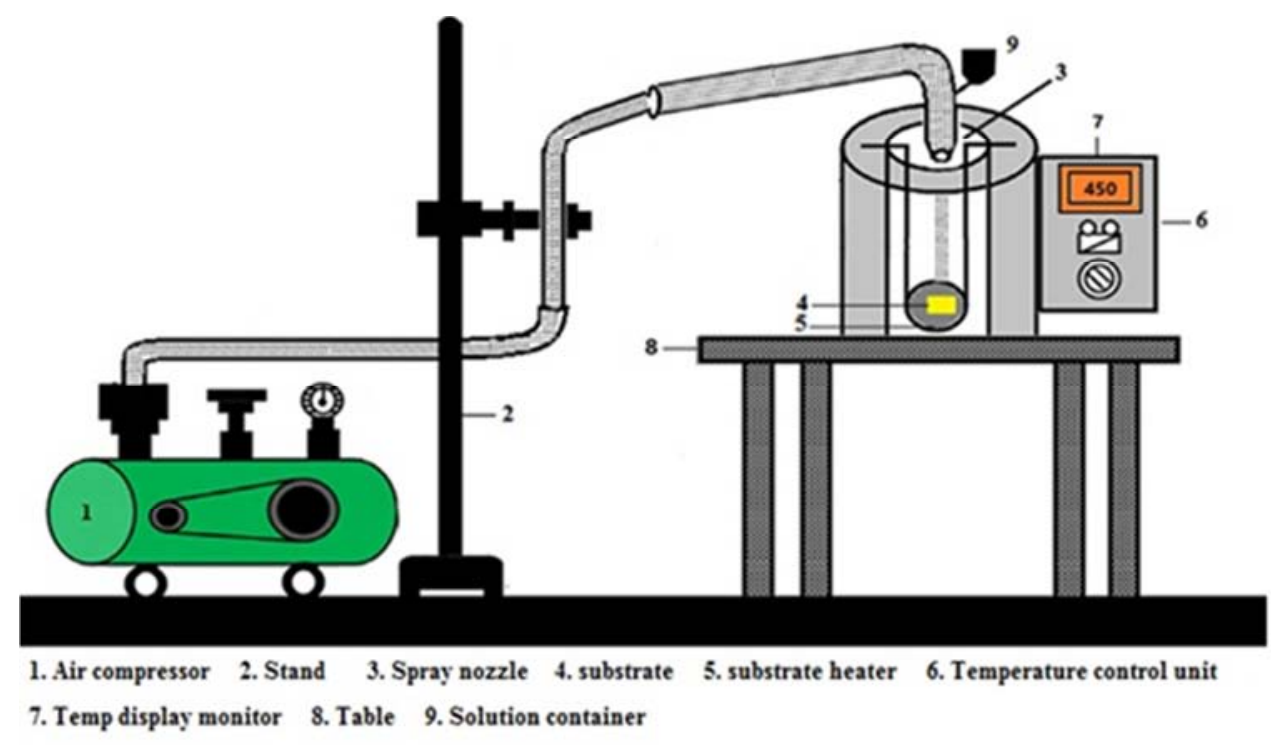

Figure 2. Schematic diagram of the spray pyrolysis apparatus.

A close control of the spraying parameters such as doping, substrate temperature, uniformity of temperature throughout the substrate etc., produces films with the required properties like high visible transmittance and low resistivity.

Generally in spray pyrolysis, the chemical reaction of thin film formation of $\mathrm{SnO}_{2}$ is as follows [12]:

$$
\mathrm{SnCl}_{4}+2 \mathrm{H}_{2} \mathrm{O} \rightarrow \mathrm{SnO}_{2}+4 \mathrm{HCl}
$$

\section{Results and Discussion}

\subsection{Optical Properties}

The optical transmission spectra of the films (T\%), were recorded using a UV-VIS-NIR double beam spectrophotometer (Jasco V-570). In order to compare the 
transparency of $\mathrm{SnO}_{2}: \mathrm{Mg}$ thin films with various $\mathrm{Mg}$-doping levels, six samples $(0,1,3,5,7$ and $9 \mathrm{wt} \%)$ were selected and then their optical spectra in the VIS-NIR region were measured $(400-900 \mathrm{~nm})$. The optical transparency and absorbency of $\mathrm{SnO}_{2}: \mathrm{Mg}$ thin films for various $\mathrm{Mg}$-doping levels are shown in Figure 3 and Figure 4 respectively.

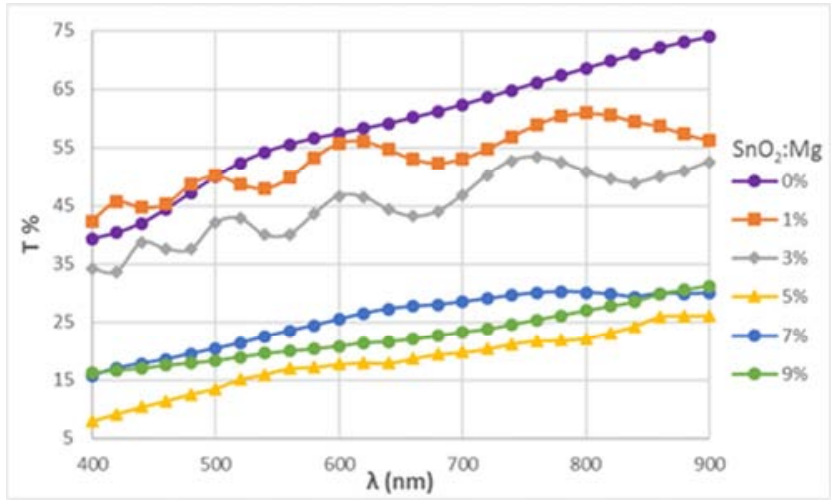

Figure 3. Optical transmission spectra of the $\mathrm{SnO}_{2}: \mathrm{Mg}$ films.

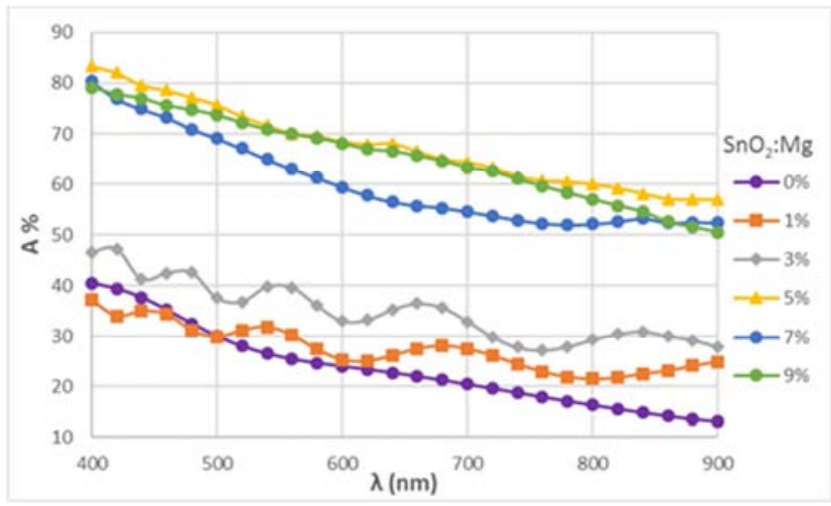

Figure 4. Optical absorption spectra of the $\mathrm{SnO}_{2}: \mathrm{Mg}$ films.

The average optical transmittance of samples in the wavelength region (400-900 nm) decreases with values (58.99\%, 53.34\%., 45.14\%, 25.44\%, 22.63\%) by increasing $\mathrm{Mg}$ - doping level $(0,1,3,7,9 \mathrm{wt} \%)$ respectively, except Mg-doping level 5wt\% (18.21\%).

The interpretation as the film with $5 \mathrm{wt} \%$ doping level which has the lowest transmittance and the highest absorbance will be explained by scanning electron microscope graphs.

The optical absorbance values are calculated using the relation [13]:

$$
\mathrm{A}=\log (1 / \mathrm{T})
$$

Optical band gap $\left(\mathrm{E}_{\mathrm{g}}\right)$ of $\mathrm{SnO}_{2}$ and $\mathrm{Mg}: \mathrm{SnO}_{2}$ thin films was estimated using the relation in the region [300-900 nm] [13]:

$$
(\alpha h v)^{2}=\mathrm{A}\left(\mathrm{h} v-\mathrm{E}_{\mathrm{g}}\right)
$$

where $\mathrm{A}$ is a constant, $\alpha$ is the absorption coefficient and $\mathrm{h} v$ is the photon energy.

The absorption coefficients $(\alpha)$ were determined by means of the optical transmittance spectra using the relation [14]:

$$
\alpha=(1 / \mathrm{d}) \ln (1 / \mathrm{T})
$$

where $\mathrm{d}$ is the thickness and $\mathrm{T}$ is the transmittance of the film at a particular wavelength.

The direct allowed transition energy of the prepared films was estimated from the plot drawn between $(\alpha h v)^{2}$ and energy of the photon by extrapolating in order to extend the linear portion of the curve to reach the photon energy axis. The $\mathrm{E}_{\mathrm{g}}$ values are in the range of 3.76-3.90 eV (Figure 11). The optical band gap of undoped $\mathrm{SnO}_{2}$ thin film is $3.90 \mathrm{eV}$ and it decreases with increasing $\mathrm{Mg}$ doping concentration except $5 \mathrm{wt} \%$ doping level whereupon $\mathrm{E}_{\mathrm{g}}$ increases up to $3.88 \mathrm{eV}$ and then it decreases gradually again (5 to $9 \mathrm{wt} \%$ ). Undoped $\mathrm{SnO}_{2}$ thin film has the maximum band gap (3.90 $\mathrm{eV})$ and the low band gap $(3.76 \mathrm{eV})$ is obtained for $9 \mathrm{wt} \%$ $\mathrm{Mg}: \mathrm{SnO}_{2}$ thin film.

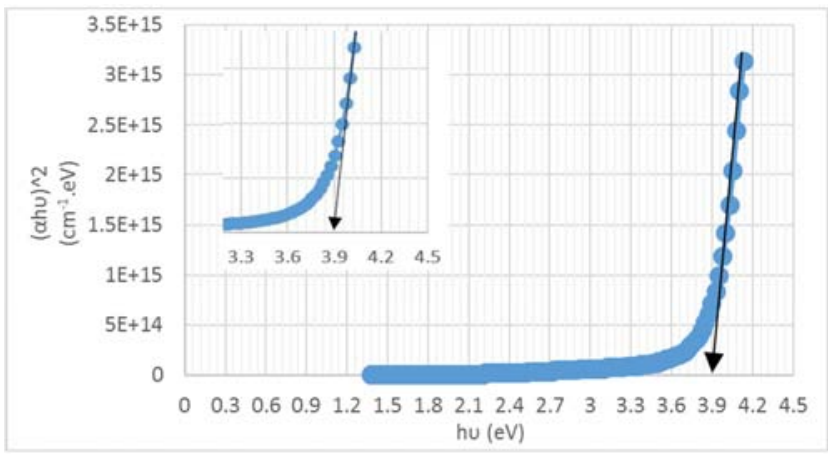

Figure 5. The variation of $(\alpha h v)^{2}$ versus $h v$ for undoped $\mathrm{SnO}_{2}$ film.

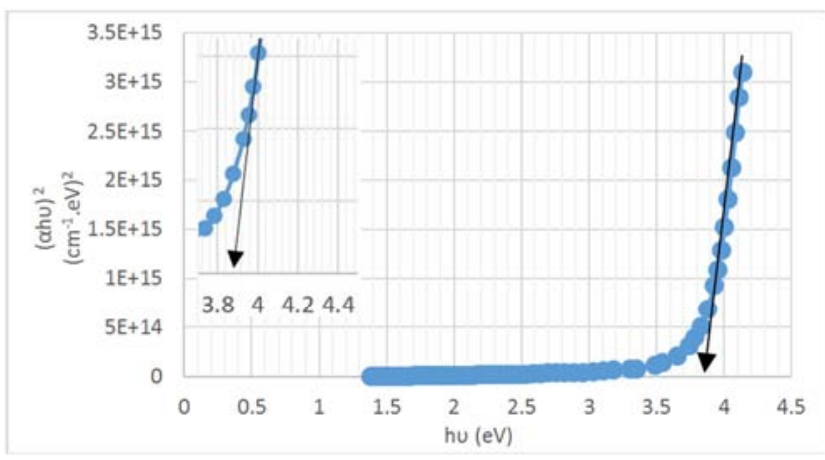

Figure 6. The variation of $(\alpha h v)^{2}$ versus $h v$ for $\mathrm{Mg}: \mathrm{SnO}_{2}(1 w t \%)$ film.

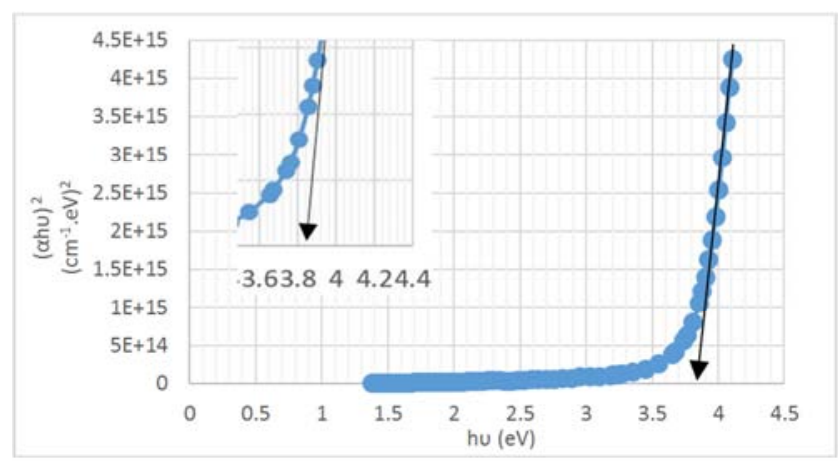

Figure 7. The variation of $(\alpha h v)^{2}$ versus $h v$ for $\mathrm{Mg}: \mathrm{SnO}_{2}(3 w t \%)$ film. 


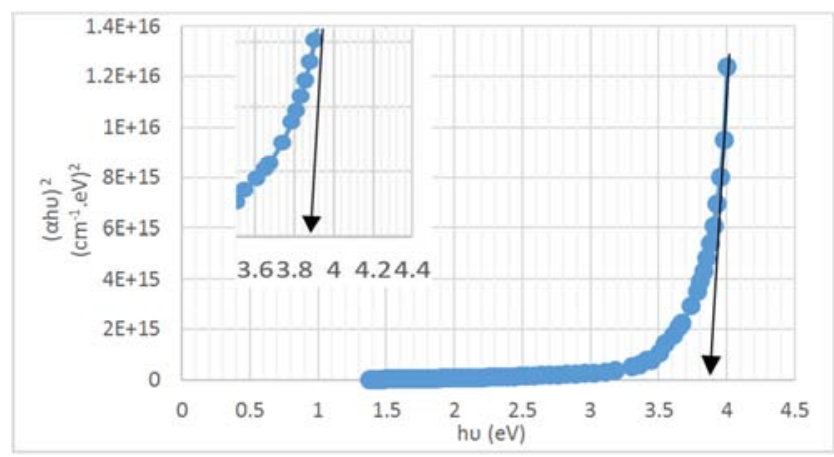

Figure 8. The variation of $(\alpha h v)^{2}$ versus $h v$ for $\mathrm{Mg}: \mathrm{SnO}_{2}(5 \mathrm{wt} \%)$ film.

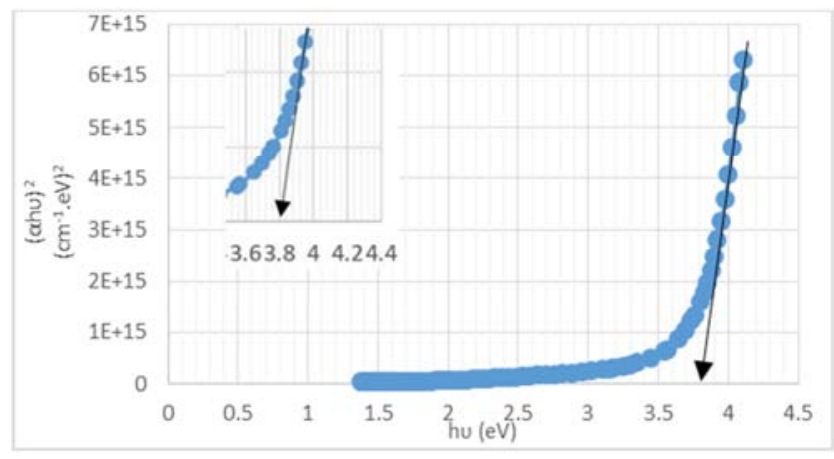

Figure 9. The variation of $(\alpha h)^{2}$ versus $h v$ for $\mathrm{Mg}: \mathrm{SnO}_{2}(7 \mathrm{wt} \%)$ film.

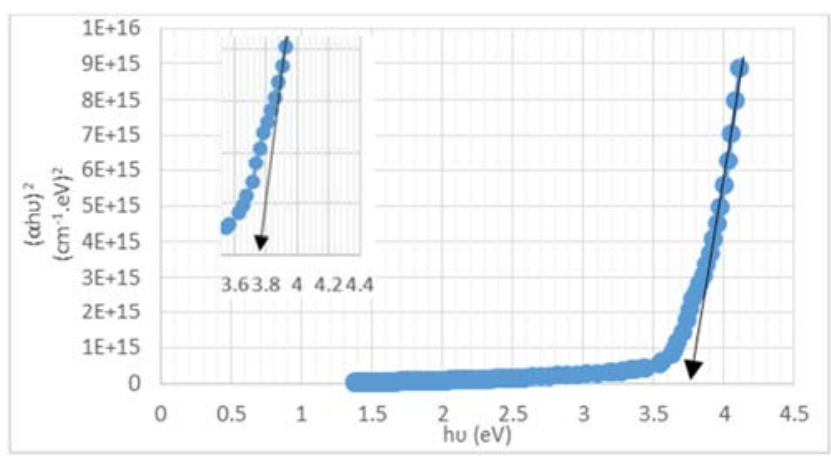

Figure 10. The variation of $(\alpha h v)^{2}$ versus $h v$ for $\mathrm{Mg}: \mathrm{SnO}_{2}(9 \mathrm{wt} \%)$ film.

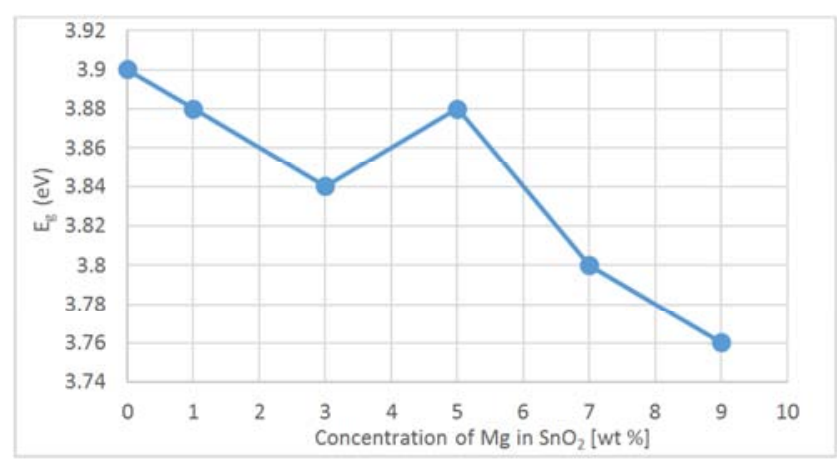

Figure 11. The variation of optical band gap with different concentrations of Mg dopant.

\subsection{SEM Analysis}

The undoped and $\mathrm{Mg}$ doped $\mathrm{SnO}_{2}$ thin films were studied by scanning electron microscope (Quanta 200) with magnification 1600x. SEM micrographs of undoped and $\mathrm{Mg}$ doped $\mathrm{SnO}_{2}$ thin films are shown in Figure 12.

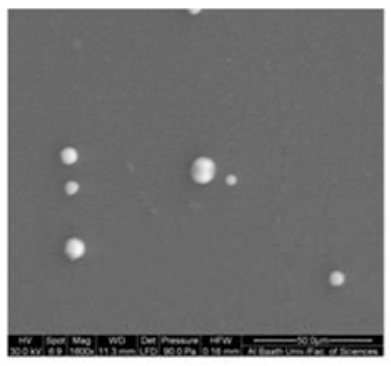

a) undoped

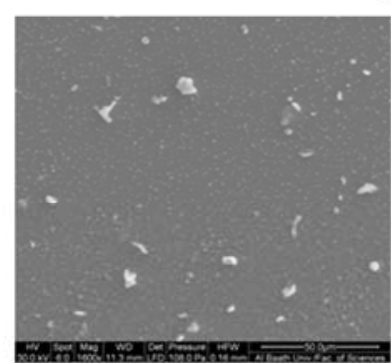

b) $1 \mathrm{wt} \%$

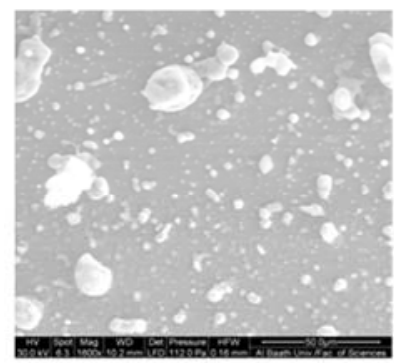

d) $5 \mathrm{wt} \%$

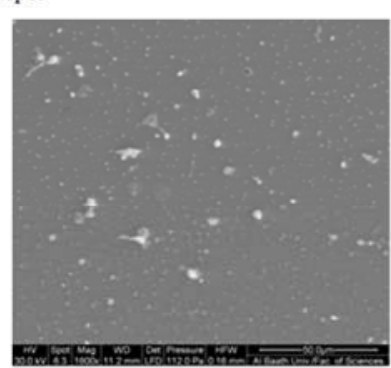

c) $3 w t \%$

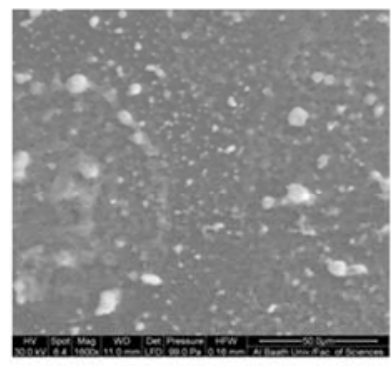

e) $7 w t \%$
Figure 12. SEM micrographs of (a) undoped, (b) 1 wt\%, (c) $3 w t \%$, (d) 5 $w t \%$, (e) $7 \mathrm{wt} \% \mathrm{Mg}$ doped $\mathrm{SnO}_{2}$ thin films.

It can be observed from Figure 12, Figure 3 and Figure 4 with increasing grains size that the transmittance decreases and the absorbance increases. This explains the fact that $5 \mathrm{wt} \%$ film has the lowest transmission and the highest absorption.

\section{Conclusions}

Effect of Mg-doping on the properties of $\mathrm{SnO}_{2}$ thin films prepared by the spray pyrolysis method was studied by varying the dopant concentration. The $\mathrm{Mg}$-doped $\mathrm{SnO}_{2}$ films were deposited on glass substrates with dopant concentrations ranging from 0 to $9 \mathrm{wt} \%$ (with $2 \mathrm{wt} \%$ step). The average transmittance of the undoped and doped $\mathrm{SnO}_{2}$ films decreases with increasing $\mathrm{Mg}$ concentration except $5 \mathrm{wt} \%$ doping level. The optical band gap of undoped $\mathrm{SnO}_{2}$ thin film is $3.90 \mathrm{eV}$ and it decreases with increasing $\mathrm{Mg}$ doping concentration except $5 \mathrm{wt} \%$ doping level where $\mathrm{E}_{\mathrm{g}}$ increases up to $3.88 \mathrm{eV}$ and then it decreases again with increasing dopant concentration till $3.76 \mathrm{eV}$ at $9 \mathrm{wt} \%$. SEM micrographs show that the grains have different sizes and they also confirm the relation between decreasing in transmittance values and increasing in grains size. 


\section{References}

[1] M. BENHALILIBA, C. E. BENOUIS, Y. S. OCAK, F. YAKUPHANOGLU (2012), "Nanostructured Al Doped $\mathrm{SnO}_{2}$ Films Grown onto ITO Substrate via Spray Pyrolysis Route", Journal of Nano- and Electronic Physics, Vol. 4, No. 1, pp. 13.

[8] MOHAMMAD-MEHDI BAGHERI-MOHAGHEGHI, MEHRDAD SHOKOOH-SAREMI (2004) "Electrical, Optical and Structural Properties of Li-Doped $\mathrm{SnO}_{2}$ Transparent Conducting Films Deposited by The Spray Pyrolysis Technique: a Carrier-Type Conversion Study", Semiconductor Science and Technology, 19, pp. 764-769.

[9] A. R. BABAR, S. S. SHINDE, A. V. MOHOLKAR, C. H. BHOSALE, J. H. KIM, K. Y. RAJPURE (2010) "Structural and Optoelectronic Properties of Antimony Incorporated Tin Oxide Thin Films", Journal of Alloys and Compounds, pp. 416-422.

[10] VIJAYALAKSHMI S., VENKATARAJ S., Subramanian M., JAYAVEL R. (2008) "Physical Properties Of Zinc Doped Tin Oxide Films Prepared by Spray Pyrolysis Technique", Journal of Physics D: Applied Physics, 41, pp. 210-216.

[3] TURGUt G., KESKENLER E. F., Aydin S., SONMEZ E., DOGAN S., DUZGUN B., ERTUGRUL M. (2013), "Effect of $\mathrm{Nb}$ Doping on Structural, Electrical and Optical Properties of Spray Deposited $\mathrm{SnO}_{2}$ Thin Films", Super lattices and Microstructures, 56, pp. 107-116.

[4] GANDHI T., BABU R. \& RAMAMURTHI K. (2013) "Structural, Morphological, Electrical and Optical Studies of Cr Doped $\mathrm{SnO}_{2}$ Thin Films Deposited by The Spray Pyrolysis Technique", Materials Science in Semiconductor Processing, 16, pp. 427-479.

[5] JARZEBSKI Z. \& MARTON J. (1976) "Physical Properties of $\mathrm{SnO}_{2}$ Materials", Journal of the Electrochemical Society, pp. 199-205.

[6] KHANAA V. \& MOHANTA K. (2013) "Synthesis and Structural Characterization of $\mathrm{SnO}_{2}$ Thin Films Prepared by Spray Pyrolysis Technique", International Journal of Advanced Research, 1 (7), pp. 666-669.

[7] RAÜL DÍAZ DELGADO, "Tin Oxide Gas Sensors: An Electrochemical Approach", Ph. D Thesis, Universitat De Barcelona, 2002.

[11] PEREDNIS D. \& GAUCKLER L. (2005) "Thin Film Deposition Using Spray Pyrolysis", Journal of Electroceramics, 14, pp. 103-111.

[12] BABAR A. \& RAJPURE K. Y. (2015) "Effect of Intermittent Time on Structural, Optoelectronic, Luminescence Properties of Sprayed Antimony Doped Tin Oxide Thin Films", Journal of Analytical and Applied Pyrolysis, 112, pp. 214-220.

[13] T. INDIRA GANDHI, R. RAMESH BABU, K. RAMAMURTHI, M. ARIVANANDHAN (2016) "Effect of Mn Doping on The Electrical and Optical Properties of $\mathrm{SnO}_{2}$ Thin Films Deposited by Chemical Spray Pyrolysis Technique", Thin Solid Films, 598, pp. 195-203.

[14] SIBEL GÜRAKAR, TÜLAY SERIN, NECMI SERIN (2014) "Electrical and microstructural properties of $(\mathrm{Cu}, \mathrm{Al}, \mathrm{In})-$ doped $\mathrm{SnO}_{2}$ films deposited by spray pyrolysis", Advanced Materials Letters, 5 (6), pp. 309-314. 